\title{
Editing Experiment:
}

\section{The New Modernist Editing and Dorothy Richardson's Pilgrimage}

[Needs abstract and keywords per MC guidelines: https://www.euppublishing.com/page/mod/submissions]

What does it mean to say a modernist text is experimental? This is one of the main questions that Dorothy Richardson's thirteen-volume novel sequence Pilgrimage poses for those of us involved in the Dorothy Richardson Editions Project, inaugurated in 2007 with the aim of producing new scholarly editions for Oxford University Press of Richardson's fiction and letters. Pilgrimage is an example of a modernist artwork that elicited claims of experiment from the moment it emerged. 'Miss Dorothy Richardson has mastered her own medium, and the experiment is of the very greatest interest and suggestion', one reviewer writes of The Tunnel (1919), the fourth volume of the sequence. A reviewer of Oberland (1927), the ninth volume, describes the whole sequence as a 'series of experiments'. ${ }^{1}$ Reflecting a mid-century cultural mainstream hostile to high modernism, Christopher Ricks defends Pilgrimage in 1967 by portraying its 'experiments (vivid and incidental)' as less praiseworthy than its more 'traditional achievements'. ${ }^{2}$ To this day, the word experiment in literary criticism often serves merely as a shorthand for formal innovation, or even as a synonym for modernist aesthetics in general. But these critics detect the particularity of individual experiments rather than a vague essence of 'experimentalism' in Pilgrimage. It is therefore such tangible experiments that demand the attention of Pilgrimage's editors.

Experiment has been relatively untheorised within modernist aesthetics. Theodor Adorno has been one of the few critics to attempt to identify its distinguishing features. In his Aesthetic Theory, Adorno's discussion centres on the question of agency and precedent. He begins by stating that the 'violence of the new, for which the name "experimental" was adopted is not to be attributed to the subjective convictions or the psychological character of the artist'; instead, when 'impulse [Drang] can no longer find preestablished security in forms or content, productive artists are objectively impelled [gedrängt] to experiment'. Having established experiment at the heart of the artistic process, Adorno then notes a historical transformation within the very concept of experiment itself, a transformation that is 'exemplary for the categories of the modern':

Originally [experiment] meant simply that the will, conscious of itself, tested unknown or unsanctioned technical procedures. Fundamental to this idea of experiment was the latently traditionalistic belief that it would automatically become clear the results were a match for what had already been established and could thus legitimate themselves. This conception of artistic experimentation became accepted as obvious at the same time that it became it became

\footnotetext{
1 'The Tunnel', Daily Telegraph, 28 March 1919, p. 12; 'Various Enchantments Plain \& Coloured', Glasgow Herald, 1 December 1927, p. 6.

${ }^{2}$ Christopher Ricks, 'Powerful Cross-Current', Sunday Times, 23 April 1967, p. 50
} 
problematic in its trust in continuity $[. .$.$] now it means something qualitatively different: that the$ artistic subject employs methods whose objective results cannot be foreseen $[. .$.$] The concept of$ construction [Konstruktion], which is fundamental to the modern always implied the primacy of constructive methods over subjective imagination. ${ }^{3}$

Richardson fits Adorno's theory of the experimental artist in that she was impelled to create a new form of narrative because of the inadequacies of existing models, in particular what she saw as the 'conducted tour' performed by the nineteenth-century realist novel:

The material that moved me to write would not fit the framework of any novel I had experienced. I believed myself to be, even when most enchanted, intolerant of the romantic and the realist novel alike. Each, so it seemed to me, left out certain essentials and dramatised life misleadingly. Horizontally. Assembling their characters, the novelists developed situations, devised events, climax and conclusion. I could not accept the finalities. Always, for charm or repulsion, for good or ill, one was aware of the author and applauding, or deploring, his manipulations. This, when the drama was a conducted tour with the author deliberately present telling his tale. ${ }^{4}$

Richardson's point of reference is not the novel form, which no longer offers what Adorno calls 'preestablished security' for the artist. Instead, she experimented with what Adorno calls 'constructive methods'. In Aesthetic Theory, the concept of Konstruktion, which can mean both 'construction' and 'design', 'necessitates solutions' the outcome of which cannot be entirely foreseen: 'that the imagining ear or eye does not immediately encompass or know in full detail'. ${ }^{5}$ To describe Richardson's modernism in this way is not at odds with Richardson's critics quoted above: their vocabulary for Richardson's experiments - interesting, suggestive, serial, vivid, incidental - imply that Pilgrimage is written as a process, without precedent or certainty. But this does present particular problems for her editors.

Pilgrimage was begun as a project seemingly without a predictable endpoint. It consists of a series of 'chapter-volumes', written over four decades: volumes appeared between 1915 and 1938, at first yearly, then at longer intervals, until a last posthumous, unfinished volume, March Moonlight, was published for the first time in an extended collected edition of $1967 .{ }^{6}$ The sequence explores the

\footnotetext{
${ }^{3}$ Theodor W. Adorno, Aesthetic Theory, trans. Robert Hullot-Kentor (London: Bloomsbury, 2013), p. 33. Translation modified.

${ }^{4}$ Richardson, 'Data for Spanish Publisher', ed. by Joseph Prescott, London Magazine, June 1959, pp. 14-19 (p. 19).

5 Theodor Adorno, Äesthetische Theorie, Schriften Vol.7 (Frankfurt am Main: Suhrkamp Verlag, 1970), p. 43.

${ }^{6}$ The term 'chapter-volume' is Richardson's own for describing the individual novels that make up Pilgrimage. Since in this article we also discuss the chapter itself as a unit within these 'chapter-volumes', for clarity, we use the term 'volume' throughout.
} 
ongoing experience of its protagonist, Miriam Henderson, from whose point of view the narration proceeds without any explanatory context or external narratorial perspective. To understand any individual volume of Pilgrimage properly requires not just an understanding of its surrounding narrative context, but also an understanding of its place within the sequence's developing, experimental form. The sequence's lack of an endpoint means that there is no finished point at which the editor might consider the text complete. While all texts are unstable, in the case of Richardson, as with many modernist works, the text is deliberately unstable, consciously a work in progress.

\section{Pilgrimage's Constructive Methods}

Across the time of Pilgrimage's composition, Richardson tried out a range of different experimental, 'constructive methods', each of which risked the possibility of their own failure. At every level, from the micro-structure of the sentence to the internal structures of sections, chapters, and volumes, Richardson's aim was for an open design marked by gaps and silences that grant the reader a collaborative role in the creation of the narrative. This disruptive technique starts at the level of the sentence, where Richardson experimented with punctuation in order first to arrest the reader and then invite their participation.

In the manuscript of Pointed Roofs - the initial volume of the sequence, and one of only four manuscripts that survive - Richardson makes frequent use of ellipses, often of four dots or more. ${ }^{7}$ These were regularised in the first edition, consisting only of three or four dots. In the following example from the first edition of Pointed Roofs (1915), the ellipses operate to represent a fragmented consciousness in which past, present, and future interact in contradictory ways:

How lovely it would be to-day at the end of the day. Fräulein would feel happy then . . or did elderly people fear cancer all the time. ... It was a great mistake. You should leave things to Nature. .. . You were more likely to have things if you thought about them. But Fräulein would think and worry . . . alone with herself . . . with her great dark eyes and bony forehead and thin pale cheeks ... always alone, and just cancer coming ... I shall be like that one day ... an old teacher and cancer coming. It was silly to forget all about it and see Granny's calceolarias in the sun ... all that had to come to an end. .. . To forget was like putting off repentance. Those who did not put it off saw when the great waters came, a shining figure coming to them through the flood. . . . If they did not they were like the man in a night-cap, his mouth hanging open-no

\footnotetext{
7 There are two other extant manuscripts of the published chapter-volumes: an autograph manuscript of Dawn's Left Hand, which has some typed sections towards the end, and one of Dimple Hill. The unpublished March Moonlight survived as typescript and a collection of autograph drafts and notes.
} 
teeth—and skinny hands, playing cards on his death-bed. ${ }^{8}$

In the surviving manuscript of Pointed Roofs, the number of dots used for the ellipses in this passage ranges from two to seven. ${ }^{9}$ Longer and more varied ellipses are included in the later published volumes of the sequence, as if Duckworth, Richardson's publisher, allowed her more latitude once she had been publically recognised as an experimental writer. Consequently, there is a critical case to be made for the deficiencies of the earlier published parts of Pilgrimage because of their lack of fidelity to Richardson's original vision. The passage above could serve as a locus classicus for the modernist novel, with its central character's reflections on their everyday world mingling with distant memory and the anticipation of death. If the precision of its effects comes in part through the juxtaposition of phrases and the separation of these phrases by ellipses, then such effects would only be heightened through a more faithful rendering of Richardson's manuscript. At the least, for editors of modernism, a historicallyattuned awareness of the constraints imposed by publishing conventions is essential for an understanding of the development of a given author's style.

The infrequent use of commas in this passage is another feature of Pilgrimage's early volumes. This was at first an unconscious choice, but when J. D. Beresford pointed it out to her Richardson experimented with deliberately removing commas in the later volumes, notably those that narrate Miriam's move to central London: The Tunnel and Interim. ${ }^{10}$ In her 1924 essay 'About Punctuation', Richardson describes her own approach to punctuation as one of a selection of interesting experiment[s]' that includes T. W. H. Crosland's insistence on the use of full stops and the Dadaists' 'conscious protest against everything that has been done to date by the hand of talent at work upon inspiration'. ${ }^{11}$ Positioning herself between a new conservatism and the avant-garde, Richardson argues for a principle of 'organic adaptation', making the case for utilising the 'time-value' of the comma: 'in the slow, attentive reading demanded by unpunctuated texts, the faculty of hearing has its chance, is enhanced until the text speaks itself. ${ }^{12}$ Whereas in many scholarly editions, changes to comma-usage across different versions of the same text would not be recorded in a variants list, the importance of the unpunctuated sentence to modernist prose means that its editors have to be attentive to any change in practice between versions.

After the sentence, the next level of internal structure in each volume of Pilgrimage is the sections that subdivide the chapters. Miriam says to Hypo Wilson in Pilgrimage's seventh volume, Revolving Lights, that 'there are many kinds of silence. But the test of absolutely everything in life is the

\footnotetext{
${ }^{8}$ Dorothy Richardson, Pointed Roofs (London: Duckworth, 1915), pp. 287-8.

${ }^{9}$ This manuscript is held in Series II, the Dorothy Richardson collection, Beinecke Rare Book and Manuscript Library, Yale University. The relevant passage appears on a page that, at the top, is numbered '261' in Richardson's own hand; this pagination is not indicative of the manuscript as a whole, however, since the manuscript includes numerous insertions. 10 See letter to Bryher, 28 August 1937, Bryher Papers, Beinecke Library, Yale University.

${ }^{11}$ Dorothy Richardson, 'About Punctuation', The Adelphi 1 (April 1924), pp. 993-4.

12 ‘About Punctuation', pp. 994-5, 990.
} 
quality of the in-between silences'. ${ }^{13}$ The manuscript of Pointed Roofs and subsequent editions show Richardson trying out different approaches to the 'in-between silences' created by the section breaks. ${ }^{14}$ The manuscript of Pointed Roofs reveals the importance of these subdivisons to its design. The jumps between sections mark significant shifts in time and mood and, perhaps surprisingly, the numbers amplify the disruptive effect because the temporal logic of the sections does not follow the formal expectation of linear succession the numbers imply. The consequence is that instead of being led by continuous action, the narrative is governed by Miriam's developing consciousness, where memory and desire co-exist and interact with her immediate experience.

The manuscripts and first editions show that Richardson experimented with different ways of marking section breaks. Pilgrimage's open design called for a flexible approach and Richardson's experimental technique meant that her approach to its structure was constantly evolving. In the first five volumes of the sequence the sections are numbered. With the fifth of these volumes, Interim, Richardson expands her repertoire for ordering her texts, with some chapters' sections numbered with Arabic and others with Roman numerals, and some individual sections frequently divided again with line breaks. The section numbers disappear in the next volume, Deadlock, in which there are very few section breaks, two of which are marked with five, centred equidistant dots. In Revolving Lights, there are only a few single-line, unnumbered gaps. The eighth volume, The Trap, reverts to numbered sections, but uses single-line gaps to further subdivide the long final numbered section of the final chapter. Oberland uses mise-en-page as a unit of signification, distinguishing between three, four, and six-line gaps. From the eleventh volume of Pilgrimage, Dawn's Left Hand, Richardson drops chapters altogether, employing only sections divided by spaces written into the manuscript with the number of lines in the gap specified, although these instructions were not followed exactly by the compositor. Clear Horizon is organised in the same way, apart from three sections divided by asterisks. The surviving manuscript of the first two thirds of Dimple Hill - the twelfth volume of the sequence - follows the same pattern. Up until 1935 (the date of the Dimple Hill manuscript), Richardson seems to have been happy to alter her practice with each new volume.

Where there is no manuscript, it is difficult to know how far the spacing between sections on the page of the first editions is the result of Richardson's specification or the work of the compositor. Nonetheless, all available evidence suggests that the division into sections was an essential element of Pilgrimage as a whole, fragmenting the narrative to give the reader a chance to reconfigure it into a new constellation. The manuscript of Pointed Roofs shows the signifying potential Richardson saw in the division and subdivision of her work. At one point, for example, the manuscript registers Richardson's change of heart related to the placement of Chapter V: the header for this chapter is inserted in place of the marking for a section break. At the top of the same page Richardson writes then crosses out:

\footnotetext{
${ }^{13}$ Dorothy Richardson, Revolving Lights (London: Duckworth, 1923), p. 244.

${ }^{14}$ For a detailed discussion of Richardson's use of gaps and silences see Annika Lindskog, Silent Modernism: Soundscapes and the Unsayable in Richardson, Joyce, and Woolf (Lund: Centre for Languages and Literature, Lund University, 2017), pp. $135-76$.
} 


\section{Break up}

\section{$\underline{\text { More sections }^{15}}$}

Throughout the manuscript, section numbers are changed and new breaks inserted in the margin. The manuscripts of Dawn's Left Hand and Dimple Hill show a similar concern with the narrative's internal organisation. The composition of Pilgrimage is characterised by the interplay between design and accident. Indeed, one might say that Richardson created a design that allowed for accident, yet the gaps and absences that open the text to the contingencies of the reader's interpretation also create extra uncertainties in Richardson's manuscripts, which can easily translate into errors when the manuscript is translated into print.

Richardson seems to have recognised this problem, but often blamed herself or her conditions of work rather than seeing it has intrinsic to her method. From the start, Richardson was relentlessly critical of her work, never feeling she had found the optimum conditions for creation nor achieved her aims. ${ }^{16}$ In a letter to the First World War poet, Robert Nichols, she willingly agrees with the opinion of the neurologist Henry Head, who preferred Pointed Roofs to Backwater as a work of art: 'I think it has a beauty that is lacking in Backwater - though there's better stuff in the later Volume. ${ }^{17}$ She was often despairing about Pilgrimage's progress, or lack thereof, and at times thought she would have to give up. She burned the first draft of Clear Horizon because of its 'trite, abstract propositions' ${ }^{18}$ Looking back in 1944, she wrote to her friend and patron Bryher:

I well remember how very often I had to write against passage after passage I.R. meaning imperfectly realised, or TMD meaning too much description. And always, in sending a volume to press, despairingly felt that the whole needed these comments and a complete re-writing. ${ }^{19}$

Yet earlier on she could also be more optimistic, seeing failure as part of the creative process.

Encouraging Robert Nichols in his own work, in August 1918 she wrote that 'Every "thing” fails. But every "thing" is an amazing extra added to "everything"; \& each brings its flash of revelation. A little further on, nothing fails'. ${ }^{20}$

One of the remarkable things about Pilgrimage is Richardson's willingness to incorporate the risk

\footnotetext{
15 This page is numbered ' 105 ' in the manuscript (see also n. 9 above).

${ }^{16}$ Looking back in a letter to Bryher in 1946, she felt that Oberland and the The Trap were the most successful in terms of form and Revolving Lights the best example overall: See letter to Bryher 21 June 1946, in Gloria G. Fromm (ed.), Windows on Modernism, (Athens: University of Georgia Press, 1995), p. 540.

${ }^{17}$ Letter to Robert Nichols Autumn 1918, Archives and Manuscripts, British Library.

${ }^{18}$ Letter to Bryher, 15 April 1936 in Fromm (ed.), Windows on Modernism, p. 309

${ }^{19}$ Letter to Bryher, 9 May 1944, in Fromm (ed.) Windows on Modernism, p. 496. Bryher (Annie Winifred Ellerman) was a wealthy heir of the Ellerman shipping business. As well as being a writer and editor, she used her money to support struggling writers.

${ }^{20}$ Letter to Robert Nichols 27 August 1918, Archives and Manuscripts, British Library.
} 
of failure into her aesthetic, almost as a way of insuring her ongoing commitment to narrative experiment. To read Pilgrimage in terms of a dialectic between success and failure, however, raises the spectre of intentionality. This issue needs to be handled particularly carefully given the status of Pilgrimage as a form of life-writing. In broad outline, Miriam Henderson's experience is the same as Richardson's between the ages of about seventeen and forty; that Richardson used her own life as source material is not under dispute. As a consequence, Richardson's writing through Miriam Henderson's subjectivity has often been read as a form of autobiography, a re-establishment of the centrality of the ego. But despite drawing on her own life experience in Pilgrimage, Richardson corrected those who described the novel-sequence as autobiography: 'I am not Miriam', she said emphatically to the editor Edward Garnett in 1924, reaffirming to Lita Hornick that Pilgrimage 'is certainly not autobiography' in $1948 .^{21}$

Therefore, Pilgrimage's aesthetic of failure is not best measured against one individual's biography, but rather against a much more disruptive conception of modern experience. To bring Adorno back in here, Aesthetic Theory provides terms through which an experimental form of modernist life-writing conditioned on the failure of constitutive subjectivity might be understood:

Not only is the unforeseen an effect, it also has an objective dimension, which was transformed into a new quality. The subject, conscious of the loss of power it has suffered as a result of the technology unleashed by himself, raised this powerlessness to the level of a program and did so perhaps in response to an unconscious impulse to tame the threatening heteronomy by integrating it into subjectivity's own undertaking as an element in the process of production. ${ }^{22}$

Richardson advocated 'egoism', but her egoism, derived from Max Stirner via Dora Marsden's anarchist feminism, was a route to something else. ${ }^{23}$ Pilgrimage troubles rather than confirms the stable, constitutive subject; the sequence's very particular approach to rendering Richardson's own subjective experience becomes a 'technology unleashed' by Richardson. Adorno's subject threatened by heteronomy is revealed in the numerous passages in Pilgrimage that move from the third to the first and then back to the third person. If Pilgrimage is about the self, Richardson's experimental form disrupts the illusion of the subject's autonomy, all the way through from the facts of its composition to its own aesthetic characteristics. We might employ another philosophical formulation of Adorno's - from Negative Dialectics - to describe Richardson's method as using 'the strength of the [represented] subject

\footnotetext{
${ }^{21}$ Edward Garnett, 'Women of the Day: Miss Dorothy Richardson', Yorkshire Post, 3 March 1924, p. 12; Richardson to Lita Hornick, 20 December 1948, Kulchur Archives, Rare Book and Manuscript Library, Columbia University. As Joanne Winning has shown, in the case of Pilgrimage, "the autobiography as form is a palimpsestic "intratext," a hybrid genre of "truth" and "fiction," particularly when complicated by the effects of gender and sexual identity on self-representation' (The Pilgrimage of Dorothy Richardson (Madison, WI and London: University of Wisconsin Press, 2000), p. 39).

22 Adorno, Aesthetic Theory, p. 33.

${ }^{23}$ For Richardson on feminine egoism, see 'Women and the Future', Vanity Fair, April 1924, pp. 39-40.
} 
to break through the fallacy of constitutive subjectivity'. ${ }^{24}$

\section{Editing Pilgrimage}

Pilgrimage's experimentalism performs an intricate and irreducible dialectic between writing and experience. Its shifting and constantly unfolding artistic processes are grounded on and incorporate the recurring possibility of their own failure. Such claims would conventionally be assumed to be the literary critic's domain. But our contention is that they equally pose challenges and opportunities to the scholarly editor. We argue that editing Richardson's writing calls for a process that is itself prepared to risk failure, in particular the (re)production of a Pilgrimage that aims to preserve Richardson's principles of experimental inconsistency. In a broader sense, Richardson provides a rich case study that demonstrates how the experimental character of literary modernism calls for new, experimental forms of editorial practice.

However, to edit Pilgrimage is not just to edit it anew, but to intervene in a longer editorial history of Richardson's writing, because the very notion of editing was immanent within the production and circulation of Richardson's work from its inception. Perhaps the most significant editorial event in this history took place in the late 1930s. Richardson's changing approach to narrative shape and chapter arrangement is not visible to the majority of Richardson's readers today, because for over threequarters of a century Pilgrimage has circulated mainly in a collected edition. This edition was published first in the UK in 1938 by Dent and the Cresset Press as a four-volume collection of twelve novels (including the first ever publication of Dimple Hill); Dent reprinted this collection in 1967 with a new introduction by the critic Walter Allen and March Moonlight appended to the fourth volume. Finally, in 1979, Virago Press reprinted this thirteen-volume sequence with a new introduction by the Richardson scholar Gillian Hanscombe. The latter is still today the most readily available version of Pilgrimage. In this version, the internal structure is reorganised from the first editions. Chapters divisions are reintroduced in Dawn's Left Hand and Clear Horizon. There are no chapter divisions in the manuscript of Dimple Hill, only published in the collected edition, but there are in the published version. Some chapter divisions are added, for example in Pointed Roofs. All sections are subdivided with gaps; the use of numbers and asterisks disappears. The result was a more consistent, but less experimental text.

If we view Richardson's method as constructive in Adorno's sense, then the changing forms of the first editions make sense because they propel the narrative to unforeseen ends. Inconsistency is a way of incorporating contingency. The 1938 text, on the other hand, removes some, although not all of the experimentation. Alongside the reorganisation of the shape of the 1938 text, the most striking change from the first editions is the clear subjection of Richardson's first editions to a uniform style

\footnotetext{
${ }^{24}$ Theodor W. Adorno, Negative Dialectics, trans. E. B. Ashton (London: Routledge, 1990), p. xx.
} 
guide. Titles of books and paintings originally placed in inverted commas or distinguished through capitalization are routinely and meticulously italicized; foreign words originally placed in roman type, or in inverted commas, and often misspelled are made consistent, italicized, and corrected. Particularly indicative of the text's transformation is the implementation of so-called 'Oxford spelling', which favours the -ize over the -ise suffix (realize, civilization) because, according to New Hart's Rules, it 'corresponds more closely to the Greek root of most-ize verbs, -i₹o ${ }^{25}$ In examples like these, the inconsistency of Richardson's first editions is eradicated with the establishment of style norms. This looks like Adorno's definition of pre-modernist experimentation: the 'results' of the original texts have proved not to be 'a match for what had already been established' and are thus unable to 'legitimate themselves'.

Richardson herself gave various commentaries on the process of editing for publication; these commentaries point to somewhat contradictory positions. She was generally unhappy with all of the first editions: a number of hand-corrected copies survive, such as those she sent to the American bookseller and editor John Hinsdale Thompson; in 1933 she claimed these copies to be the 'sole "definitive edition"”. ${ }^{26}$ She found the process of putting together the collected edition deepened her sense of Pilgrimage as one work. In 1936, she wrote to her good friend, the translator S. S. Koteliansky: 'I am moved to record the deepening, in the course of reading \& correcting all the little volumes, of my sense of the relative futility of publishing them separately. They support \& amplify \& clarify each other'. ${ }^{27}$ Notably, in this and other letters written around this time, she represents her changes as corrections rather than revisions. She wrote to John Cowper Powys of attacking the 'chaos', she had warned about in 'About Punctuation', which she saw as the consequence of 'Duckworth[']s efforts to standardise my punctuation \& my counter-efforts to recondition it'. ${ }^{28}$ The result, she complained to Bryher in 1937, had been her 'obstructive reputation for unreadable prose', an account she authorised in the Foreword to the 1938 edition, where she writes that her use of the comma 'helped to produce the chaos' for which she was 'justly reproached'. ${ }^{29}$

Nevertheless, when the 1938 edition was published, Richardson still didn't feel that she had been able to achieve the outcome she wanted. Writing to Claude Houghton in 1942 she commented that: 'When Dent's [1938] edition was going through, I couldn't manage much proof-reading, \& some of the p[rinters]. e[rror]'s I found, even on dipping, made me squirm' ${ }^{30}$ She also annotated a number of copies of the 1938 edition with corrections, including a full set lodged at the Public Library in Padstow,

\footnotetext{
${ }^{25}$ New Hart's Rules: The Oxford Style Guide (2nd edn; Oxford: Oxford University Press, 2014), p. 49.

${ }^{26}$ Letter to John Hinsdale Thompson, June 1933, McFarlin Library, University of Tulsa.

${ }^{27}$ Letter to S. S. Koteliansky 24 February 1936, Koteliansky Papers Vol.VII, British Library.

${ }^{28}$ Letter to Powys, 19 November 1935, in Fromm (ed.), Windows on Modernism, p. 303.

${ }^{29}$ Letter to Bryher, 28 August 1937, Bryher Papers, Beinecke Library, Yale University. Dorothy Richardson, 'Foreword', Pilgrimage Vol.1 (London: J. M. Dent, 1938), p. 12.

${ }^{30}$ Letter to Houghton, 21 December 1942, in Fromm (ed.), Windows on Modernism, pp. 454-5.
} 
Cornwall, one of her most consistent places of residence from 1915 onwards. ${ }^{31}$

Those critics who have discussed the differences between the first and the collected editions have tended to see Richardson's inconsistent practice as a consequence of poor proof-reading, faulty concentration because of difficult circumstances, and/or a change of heart. John Mepham's work is typical in this respect, speculating that by the 1938 edition, Richardson

may have felt very unsure of the rationale for some of her more radical experiments with punctuation, including those which she abandoned more or less immediately. It was as if she had come to lose confidence, in certain respects, in the experiments in unreadability that had been so important to her in the earlier, more successful years of her career. [...] The consequence of her extraordinary shifts in textual style was that while her text never descended into incoherence, that is, into unreadability in a strong sense of the term, nevertheless the difficulty had escalated beyond anything that could be made sense of by her less patient readers. She seems to have come to some such view herself when in 1938 the text was redesigned. ${ }^{32}$

In the account given by the Richardson scholar George H. Thomson, even the 1938 edition betrays a set of regrettable defects. Drawing on later letters in which Richardson reflected on the preparation of the 1938 edition, Thomson concludes that Richardson's 'good intentions, it would seem, were undermined from all sides, by the press of daily preoccupations, by boredom and impatience with proofs, and by the lure of going on with Volume V [of Pilgrimage]. ${ }^{33}$ For both Mepham and Thomson, any oddity in literary presentation is viewed teleologically, seen as either eventually rectified or mistakenly overlooked. Here, failure is an aberration or a lack, rather than an experimental condition and an aesthetic value.

Critics such as Stephen Heath come at Richardson from the opposite direction. Heath starts from the premise that Pilgrimage is an experimental work: a work without a terminus, 'an inevitably interminable project, a perpetual work on oneself. ${ }^{34}$ Recognising Pilgrimage's unfinishable, impossible form means the editor no stable fixed text from which to look back at earlier versions. This, and a desire to stay faithful to the period of high modernism in which the early chapter-volumes were published is why the new Oxford edition of Pilgrimage returns to Richardson's first editions rather than to the 1938 edition. The first editions represent Richardson's long narrative as her readers originally

\footnotetext{
31 The whereabouts of the Padstow copies is now unknown. However, a list of these corrections was recorded by Richardson's biographer Gloria Fromm. George H. Thomson incorporates Fromm's list into a broader record of corrections Richardson made in various forms to the published text of the 1938 editions: see Thomson, Notes on Pilgrimage: Dorothy Richardson Annotated (Greensboro N.C: ELT Press, 1999) pp. 276-87.

${ }^{32}$ John Mepham, 'Dorothy Richardson's “Unreadability”: Graphic Style and Narrative Strategy in a Modernist Novel', English Literature in Transition, 1880-1920, 43 (2000): 449-64 (p. 462).

33 George H. Thomson, 'Introduction' in George H. Thomson with Dorothy F. Thomson, The Editions of Dorothy Richardson's Pilgrimage: A Comparison of Texts [ebook] (Greenboro, NC: ELT Press, 2001), n.p.

34 Stephen Heath, 'Writing for Silence: Dorothy Richardson and the novel', in Susanne Kappeler and Norman Bryson (eds), Teaching the Text (London: Routledge Kegan Paul, 1983), p. 128.
} 
received it. In this sense, the first editions are historical products of early twentieth-century modernism as it was at the time, rather than as it was reconceived in retrospect in 1938. Further, although there is evidence that Richardson was not happy with the first editions - which she felt were full of errors, particularly in the punctuation - as we have seen, her letters show that she was also unhappy with the 1938 edition, so its authority as the 'consecrated' text of the first twelve volumes of Pilgrimage remains in doubt. ${ }^{35}$ It makes more sense for her editors to view Richardson as an experimental writer, whose method changed as Pilgrimage progressed. By imposing a degree of consistency on the published volumes, the 1938 edition suppresses the long process of experiment that extends from 1915 up until the surviving manuscript of Dimple Hill and then continued into the composition of the unfinished thirteenth volume, March Moonlight. Neither the first editions nor the 1938 edition are finished texts, but, in our judgement, the first editions better show the history of Pilgrimage's development as an experimental narrative.

In the new Oxford edition, a full introduction and textual apparatus supply the history of the text and show the differences with the 1938 edition. Use of the first editions and not the 1938 text means that the Oxford edition represents a new collected Pilgrimage, one that has never before been published, different from the Pilgrimage familiar to its readers in the second half of the twentieth century, and arguably one that goes against the most recent instructions of its author. As such, it requires some justification. The new Oxford edition has been guided by two principles: first, that while the fantasy of what the author's intentions might have been is never absent from the editor's imagination, those intentions are ultimately unknowable, with any argument supported only by the evidence of the surviving archive; and second, that all published texts are compromises reached after a process that involves amongst others, the author, publisher's readers, editors, compositors, and proof readers. Up until now, critics have not had access to all the Richardson materials now available, and have created their own narratives, based on some of Richardson's contradictory versions of her practice in her letters. As editors, we have relied primarily on her actual practice as documented in the few extant manuscripts and in the published versions of Pilgrimage, aided by new material from the Richardson archive.

\section{Modernist Aesthetics and the Scholarly Edition}

Without a full knowledge of Richardson's archive, the prevailing critical narrative has misunderstood

\footnotetext{
35 We take 'consecration' here in Pierre Bourdieu's sense of an 'autonomous principle of hierarchization', a form of 'literary or artistic prestige' that constitutes a 'degree of recognition accorded by those who recognize no other criterion of legitimacy than recognition by those whom they recognize'. See Pierre Bourdieu, 'The Field of Cultural Production, or: The Economic World Reversed', trans. Richard Nice, in The Field of Cultural Production: Essays on Art and Literature, ed. Randal Johnson (New York: Columbia University Press, 1993), p. 38.
} 
the role of experiment in Richardson's work, privileging instead her complaints, noted above, that Duckworth - who published the first editions of the initial ten volumes of Pilgrimage - did not understand her approach to punctuation or her own deliberately inconsistent practice. The prime piece of evidence in this narrative is Pilgrimage's fifth volume, Interim (1919). Initially serialized in the avantgarde magazine the Little Review, Interim emerges alongside the serialization of another signature modernist novel, James Joyce's Ulysses, as well as a wealth of work by other core modernist writers, such as Djuna Barnes, Ezra Pound, and William Carlos Williams. Richardson seems to take advantage of the freedom of publishing in the Little Review to extend her experiments in punctuation, with an even more radical reduction in the number of commas than in the earlier volumes, the avoidance of line breaks for speech, and the avoidance of inverted commas for speech marks, with speech sometimes denoted with long dashes and at other times not notated at all. These features are carried through to the Duckworth first edition, published the same year as the text was published in the Little Review. ${ }^{36}$

However, this self-evidently experimental practice is not followed consistently throughout the text. See, for example, the following extract from the opening of the novel's first chapter:

You've just been out, said Miriam listening to Grace's soothing reproaches for her lateness. Shall I come in or shall I burst into tears and sit down on the doorstep? Florrie laughed aloud, standing with the bag. Bring her in scolded Mrs. Philps from the dining-room door. Grace took her by the arm and drew her along the passage. I'm one mass of mud.-Never mind the mud, come in out of the rain, scolded Mrs. Philps backing towards the fire, you must be worn out. No, I don't feel tired now I'm here, oh what a heavenly fire. ${ }^{37}$

And compare it with the opening of Interim's ninth chapter, also situated on a domestic threshold:

It was Mrs. Bailey coming up the top flight clearing her throat. Tapping at the door.

"Ah. I thought the young lady was in. I thought so." Mrs. Bailey stood approving inside the door. The sunlight streamed on to her shabby skirt. ${ }^{38}$

Within the space of a single novel, Richardson moves from a complex, relentlessly shifting, and highly opaque representation of dialogue in her narrative to much more conventional means. Predictably, such inconsistency is marshalled as further evidence of Richardson's own carelessness by those critics who lament this dimension of her work. For Mepham, it is 'as if Richardson, anxious that she might have

\footnotetext{
${ }^{36}$ Among the novels that make up Pilgrimage, Interim was the only volume to be serialized in full. However, Richardson published extracts from The Trap, Oberland, and Clear Horizon in periodicals around the time of these novels' publication in book form. A number of extracts from what became March Moonlight were published in Bryher's magazine Life and Letters in 1946.

${ }^{37}$ Dorothy Richardson, Interim (London: Duckworth, 1919), p. 1.

${ }^{38}$ Richardson, Interim, p. 248.
} 
gone too far with her experiments, or that she had lost sight of her central purpose, reverted on the spur of the moment to more familiar forms of layout and notation'. ${ }^{39}$ Thomson, meanwhile, expresses equal bafflement: 'it is remarkable that Duckworth allowed the first two thirds of the novel to appear under his imprint in its radical and inconsistent Little Review format'. ${ }^{40}$

Interim is the most extreme example of the differences between Pilgrimage's first editions and the collected edition of 1938. In the 1938 edition, the passage from the opening of Interim quoted above looks quite different:

'You've just been out,' said Miriam listening to Grace's soothing reproaches for her lateness. 'Shall I come in or shall I burst into tears and sit down on the doorstep?'

Florrie laughed aloud, standing with the bag.

'Bring her in,' scolded Mrs. Philps from the dining-room door.

Grace took her by the arm and drew her along the passage.

'I'm one mass of mud.'

'Never mind the mud, come in out of the rain,' scolded Mrs. Philps backing towards the fire, 'you must be worn out.'

'No, I don't feel tired now I'm here; oh, what a heavenly fire. ${ }^{31}$

The underlying principle here is clarity, not just in the formal sense of the delineation between narration and speech, but also in the way Richardson changes the scene's capacity for representation. Most significantly, in the novel's initial form, the final comment in this passage, 'No, I don't feel tired now I'm here, oh what a heavenly fire', captures Miriam's excitement at returning to the home of her friends, her attention shifting rapidly from Mrs. Philps's comment to the newly-encountered fire. In its revised form, Miriam's comment is punctuated for legibility, its distinct sense-units carefully marked: the medial semicolon separates the two thoughts that Miriam expresses, with an additional comma separating out her rapturous 'oh' from the object to which it responds. The second passage quoted above, from Chapter IX, at least needed less alteration, since it already incorporated the principles for notating dialogue that are the norm in the 1938 edition.

In view of these kinds of textual variants, it is tempting to take the Mepham-Thomson line, seeing a straightforward teleology in Pilgrimage's development, with the 1938 edition instituting a series of ordering corrections. Interim in particular looks, therefore, like an unruly text: so much so, that even in its first edition it cannot help but register the beginnings of a process of correction. However, a recent archival discovery, found during work on the new Oxford editions of Richardson's work, offers a powerful counter-view. Mepham and Thomson were unaware of a series of instructions that

\footnotetext{
${ }^{39}$ Mepham, p. 460.

40 Thomson, 'Introduction', n. p.

${ }^{41}$ Dorothy Richardson, Pilgrimage Vol.2. (London: Dent, 1938), p. 291.
} 
Richardson sent to the Little Review regarding the presentation of dialogue and her unconventional use of commas in Interim. Titled 'Memorandum for printer's reader', Richardson dictates the following:

Please leave all dialogue as it is in the typescript i.e. sometimes as part of the text, sometimes between "dashes" \& occasionally spaced out <or> with (or without) inverted commas.

Please adhere most carefully to the punctuation, particularly safeguarding the sometimes unconventional presence, \& absence of the comma. ${ }^{42}$

Her insistence that the different kinds of punctuation are used deliberately and should not be changed explains why the Duckworth volume is so similar to the Little Review text. In this case, at least, Duckworth followed her instructions. But it also suggests that the dominant critical narrative has misunderstood her method. The problem here is a conceptual one. If Pilgrimage is seen to be aiming at an ideal form, then Richardson's inconsistent practice and variable outcomes might be read as failures or, more positively, as only partial successes, depending on how that putative ideal is formulated by the critic. If on the other hand, Richardson starts with the problem and not an ideal solution, then the volumes make sense as series of developing experiments in which different methods are tried out as responses to a larger problem of representation, something the novel in its capacity as a preeminent global literary form has hitherto been unable to address.

At the same time, the choice to return to the first editions of Pilgrimage as the source for the new Oxford editions is not an attempt to elevate the first editions within some absolute hierarchy of value. Some of the changes Richardson makes in the 1938 edition clearly represent a refinement of her defining aesthetic. In one scene in Pointed Roofs for example, Miriam attempts to avoid participating in the routine hair-washing session that takes place at the German school where she is living and working. As Miriam approaches Frau Krause, the servant assigned to wash the hair of the entire school, the first edition reads:

Soap? and horrid pudding basins of steaming water. Miriam's hair had never been washed with anything but cantharides and rose-water on a tiny special sponge.

In full horror, "Oh," she said, in a low vague voice, "It doesn't matter about me."43

In the 1938 edition, however, the second sentence ('Miriam's hair had never been washed [...]') is omitted. ${ }^{44}$ A similar deletion can be found at the start of a later section which opens with the phrase

\footnotetext{
${ }^{42}$ Undated, probably sent with the first instalment of Interim to The Little Review in May 1919, Little Review Records, University of Wisconsin-Milwaukee.

${ }^{43}$ Richardson, Pointed Roofs, p. 84.

44 See Dorothy Richardson, Pilgrimage Vol.1. (London: Dent, 1938), p. 60.
} 
'Pastor Lahmann gave a French lesson the next afternoon', before narrating Miriam's experience as she observes the class: the initial sentence here is absent in the 1938 edition, which opens instead with the next line of the first edition, the refrain of a French poem read aloud by the class alongside their teacher. ${ }^{45}$ As Rebecca Bowler notes, 'throughout Pilgrimage, the point of view is Miriam's: everything is slanted through her consciousness'. For Bowler, Richardson's literary impressionism is defined by the fact that 'the only objective description of drama possible is an objective description of a drama already received subjectively'. The two deleted sentences in Pointed Roofs skirt too closely to the kind of 'authorial interruption' that Bowler shows to be incompatible with Richardson's narrative technique. ${ }^{46}$ It is unlikely that Miriam would recall so precisely her history of hair-washing at a moment of such high anxiety and disgust, as she is hurried through the school's hair-washing production line. And a phrase like 'Pastor Lahmann gave a French lesson the next afternoon' is equally unconvincing as anything but an externally-imposed objective description of a scene, rather than Miriam's subjective apprehension thereof.

In Pilgrimage's early volumes, it is clear that the devices and norms of more traditional narrative styles occasionally slip through. The examples given here are the vestiges of an approach to narration of the sort that Richardson tried to cast off in Pilgrimage. ${ }^{47}$ It is unsurprising, therefore, that Richardson fully removed them when going over her earlier writing during the assembly of the 1938 edition: the resulting reading experience is more consistent, and Richardson's achievement in creating and sustaining a unique narrative form is even more assured. Granted, these refinements are occluded in the reversion to the first editions for a new scholarly edition; but in the context of a scholarly edition, where variants can be recorded and changes tracked, such refinements are not fully lost. The textual apparatus to the first volume of the new Oxford edition of Pilgrimage is substantial, aiming to record as many of the differences as possible between different versions of individual volumes. As noted above, a significant choice in this respect derives from the decisions that have been made regarding the designation of substantive variants between Richardson's texts, especially regarding punctuation. But in this respect, the New Modernist Editing looks much like the Old Editing: the flexibility of textual criticism, and the affordances of the conventions for a textual apparatus need not collapse under the weight of modernist innovations in literary form. ${ }^{48}$

\footnotetext{
${ }^{45}$ Richardson, Pointed Roofs, p. 167. See also Pilgrimage Vol.1, p. 106.

46 Rebecca Bowler, Literary Impressionism: Vision and Memory in Dorothy Richardson, Ford Madox Ford, H. D., and May Sinclair (London: Bloomsbury, 2016), pp. 26-7.

47 This artistic process is brought even further into relief with reference to the manuscript of Pointed Roofs. The opening of the novel, for example, is shown to be significantly reworked in its published version. For example phrases such as 'the sense of the past stirred within her', are deleted, as Richardson hones her narrative technique.

${ }^{48}$ The history of textual criticism offers so many contradictory precedents that it is large enough to encompass the complexities of a text like Pilgrimage. Looking to a seminal figure in textual criticism like W. W. Greg, for example, we can find contradictory judgements on the recording of punctuation variants. In The Calculus of V ariants (1927) punctuation 'need only be "taken down"” in a list of variants 'when it is itself in question' - despite Greg's negative formulation, he still accepts that, in certain cases, punctuation variants should be recorded. However, by the time of his famous essay 'The Rationale of Copy-Text' (1950/51), Greg promotes the 'need to draw a distinction between the significant, or as I shall call them "substantive" readings of the text, those namely that affect the author's meaning or the essence of his expression, and
} 
With their occasional slippages and awkward breaks with their own aesthetic rules, the first editions of Pilgrimage bear the marks and traces of their underlying experimental conditions. In editing Pilgrimage, the new Oxford editions try to stay true to the history of the constructive methods that led to Pilgrimage's open design. Gathering together the first editions of Pilgrimage as copy-texts is a way of tracing the sequence's development as an evolving work. To privilege these first editions is to resist the impression of finality offered by the 1938 edition. At the same time, this tension between unfinishedness and process on the one hand, and closure and totality on the other can be captured using the institution of the scholarly edition. A distinction might be made here between the editorial norms of Richardson's publishers, which have not been kind to our understanding of Richardson's experiments, and editing norms, which, once Richardson's experiments are properly understood, can fully encompass them. As the New Modernist Editing establishes itself, these kinds of distinctions can be brought out further. Indeed, perhaps scholarly editing, rather than literary criticism, is the best way to give an account of the particular ways that literary modernism developed at the interface of aesthetic practices and the mediatory structures that delivered these practices to a variety of publics.

\section{Conclusion}

Editing Richardson's experimental prose raises important questions about modernist literature itself. For Hannah Sullivan, revision - a neighbouring term to editing - is constitutive of modernism as such: modernist writers 'used revision [...] to make it new through large-scale transformations of length, structure, perspective, and genre' ${ }^{49}$ The fact that the modernist archive is so full of proto-works is a case in point: Jean Santeuil, Stephen Hero, He Do the Police in Different Voices, Mrs Dalloway's Party, John Thomas and Lady Jane, and The Pargiters, for example, are all indicative of a culture that, as Sullivan puts it, overcame 'the nineteenth-century preference for writing that was, or at least seemed to be, spontaneous' ${ }^{50}$ However, none of the editions of Pilgrimage can be characterised as revisions in Sullivan's sense. Each, including the 1938 edition, is an experiment in itself. The first editions of Pilgrimage are not comparable to Jean Santeuil and its ilk because they are not beholden to the endpoint of a final form, since, to reaffirm Stephen Heath's formulation, Pilgrimage itself is an 'inevitably interminable form?.

The fact that Richardson's first editions in particular hover somewhere between works in progress and finished artworks returns us to our point of departure. Pilgrimage challenges the

others, such in general as spelling, punctuation, word-division, and the like, affecting mainly its formal presentation, which may be regarded as the accidents, or as I shall call them "accidentals", of the text'. (Greg, The Calculus of Variants: An Essay on Textual Criticism (Oxford: Clarendon Press, 1927), p. 16; 'The Rationale of Copy-Text', Studies in Bibliography, 3 (1950/51): 19-36 (p. 21)).

${ }^{49}$ Hannah Sullivan, The Work of Revision (Cambridge, MA and London: Harvard University Press, 2013), p. 2.

${ }^{50}$ Sullivan, p. 3. 
problematic notion of autonomy in Adorno's modernist artwork. For Adorno autonomy is defined by the artwork's negative stance: 'Autonomous works of art [...] firmly negate empirical reality ${ }^{51}$ Richardson also wanted to negate a scientific, empirical model of modernity - epitomised by the writings of H. G. Wells - and her experimental aesthetic is characterized by a negative element. ${ }^{52}$ Pilgrimage might be characterised as an anti-novel; and, as we have seen, its narration from the subjective point of view of her heroine, Miriam Henderson, reveals not the autonomy, but the heteronomy of the subject. ${ }^{53}$ But there is also a positive element to Pilgrimage. Its inclination towards negative experiment is troubled by traces of the consolations Adorno thinks should be refused. In Pilgrimage, Miriam reflects that 'Life is a chain of happy moments that cannot die. ${ }^{54}$ Pilgrimage is punctuated by such 'happy moments' that make themselves known as revelations of self-presence and happenstance, irrespective of the mundanity or gravity of their conditions.

In this respect, Pilgrimage is a very different text to Adorno's preferred examples of the autonomous literary artwork: the works of Kafka and of Beckett. These are autotelic, and utopia is always resisted - in Adorno's words the 'inextinguishable color comes from nonbeing. ${ }^{55}$ But here we return to the question of gender. As an impecunious, marginal woman, non-being is not something Richardson can risk. Some kind of affirmation is essential, because she is already not. Instead, in Richardson's experiments, the dialectics of Adorno's negative utopia work out differently. The objective failure of representation is interwoven with moments when it is possible to get beyond representation to somewhere else, what Richardson describes in a manuscript fragment as 'the mass lying unexpressed behind any way of presentation I had met. Except Bunyan \& the mystics' ${ }^{56}$ It is this unrepresented 'mass' that is Richardson's 'inextinguishable colour', the inextinguishable colour not of non-being, but of being. The heteronomous self through which Pilgrimage is filtered generates not the autonomous artwork for which Adorno called, but an artwork that signals its own insufficiency - or what Adorno might call its heteronomy. Richardson's underlying principle was that Miriam's contradictions and changing understanding of the world should drive Pilgrimage from the start. Editing Pilgrimage, therefore, entails a reckoning as much with Richardson's experimental aesthetic as it does with Pilgrimage as a textual object of the sort more traditional editorial practices would understand it to be.

Yet if Pilgrimage does not quite accord with the modernist works contemporary to it, this is not to say it exists on its own, removed from any network of relations. Recent work on experimental

\footnotetext{
51 Theodor W. Adorno, 'Commitment', trans. Francis McDonagh, in Adorno et al, Aesthetics and Politics (London: Verso, 2007), pp. 177-95 (p. 190).

52 Wells is figured by the character of Hypo Wilson in Pilgrimage.

${ }^{53}$ Although Richardson describes it as a novel in the 1938 Foreword, she resisted the idea that Pilgrimage was a novel for most of her life.

${ }^{54}$ Dorothy Richardson, The Tunnel (London: Duckworth, 1919), p. 227.

55 Adorno, Negative Dialectics, p. 57.

56 'Literary Essays', autograph MS draft of an autobiographical essay on Richardson's development as a writer 2pp. Richardson Papers, Box 8, Folder 159, Beinecke Library, Yale University.
} 
women's writing has made Pilgrimage recognizable as part of a long tradition of women's writing where experiment, as Kaye Mitchell notes, 'signals a possibility, a calculated risk: to go beyond known forms, structures, and genres, to test something out, to try or attempt something new', and in which 'the experimental formal strategies of a text are germane to a consideration of its politics' so that 'experimental practice might be one (although not the only) recourse of the feminist writer. ${ }^{57}$ By virtue of the context of articulation of her writing, as well as her own social networks, Richardson will always be considered first and foremost a modernist. But if the New Modernist Editing calls for taking stock once again of the modernist archive, then through a writer like Richardson, it may also afford opportunities for rethinking the ways in which the European and North American modernism of the first half of the twentieth-century intersects with other cultural tendencies and histories that expand further outwards in time and space.

\footnotetext{
${ }^{57}$ Kaye Mitchell, 'Introduction: The Gender Politics of Experiment', Contemporary Women's Writing, 9 (2015): 1-15 (pp. 5, 8).
} 